\title{
Seroprevalence of Leptospira infection in selected rural and urban areas of Bangladesh by rLipL32 based ELISA
}

\author{
Shakila Tamanna ${ }^{1}$, Fahmida Rahman' ${ }^{1}$ TH Tang ${ }^{2}$, Siti Aminah Ahmed ${ }^{2}$, KC Ang², \\ Kaniz-E-Zannat $^{1}$, MSA Jilani ${ }^{1}$, M Mohiuddin ${ }^{1}$, J Ashraful Haq ${ }^{1}$ \\ ${ }^{1}$ Department of Microbiology, Ibrahim Medical College, ${ }^{2}$ Advanced Medical \& Dental Institute, Universiti \\ Sains Malaysia, 13200 Bertam, Kepala Batas, Pulau Pinang, Malaysia.
}

\begin{abstract}
Background and objectives: Leptospirosis is a zoonotic infection with worldwide distribution caused by the Leptospira species and predominant in the tropical and subtropical regions. Information on leptospirosis in Bangladesh is limited. The present study was designed to detect anti-leptospiral antibodies in human serum samples in Bangladeshi population by developing an in-house ELISA using recombinant LipL32 (rLipL32) antigen. The study was conducted from April 2014 to December 2014.

Method: Healthy individuals from two rural areas and fever cases from one urban healthcare center were enrolled in the study. Rural health centers were located at Sonargoan and Bajitpur sub-district (Upozilla) of Narayaganj and Kishorganj districts. Sonargoan health center is located $26 \mathrm{~km}$ south-east and Bajitpur is located $71 \mathrm{~km}$ north-east of Dhaka city. About 1-2 ml of blood was collected with aseptic measure and serum was separated and stored at -200C until used. Anti-leptospiral IgG antibody was determined by recombinant LipL32 (rLipL32) antigen based indirect enzyme linked immunosorbent assay (ELISA). Seropositive cases were further confirmed by commercial Leptospira IgG ELISA.

Results: The study included 250 febrile cases and 376 healthy individuals from urban and rural areas, respectively. Out of total 626 study population, anti-LipL32 specific IgG antibody was detected in 70 individuals $(11.2 \%)$. The rate of positivity of anti-LipL32 antibody among the healthy individuals from rural area was $10.6 \%$ while the rate was $12.0 \%$ in urban febrile population. The rate of positivity in rural and urban population was not significantly $(\mathrm{p}>0.05)$ different. Among the urban population, the rate of seropositivity was $9.1 \%$ and $16.4 \%$ in 21 40 yrs and above 40 years age group respectively while the rate was $7.2 \%$ and $14.0 \%$ in rural population respectively. Out of 70 seropositive cases detected by LipL32 ELISA, 65 (92.9\%) were positive by commercial ELISA.

Conclusion: The present study has revealed that leptospirosis is prevalent in Bangladesh and should be looked for in febrile and clinically suspected cases. The study has also demonstrated that rLipL32 protein may be used as a candidate antigen for the serodiagnosis of leptospirosis.
\end{abstract}

IMC J Med Sci 2017; 11(2): 50-55

\section{Introduction}

Leptospirosis is a spirochetal zoonosis that infrequently causes a wide spectrum of clinical manifestations in humans. Currently leptospirosis is considered as an emerging global public health problem, particularly in resource-poor countries in tropics. The burden of leptospiral disease falls predominantly on people living in poverty and under inadequate sanitary conditions. Leptospira

Address for Correspondence:

Prof. J Ashraful Haq, Professor of Microbiology, Ibrahim Medical College, 122 Kazi Nazrul Islam Avenue, Dhaka, Bangladesh.Email: jahaq54@yahoo.com 
spp infect various animals including rat and other rodents. Animal excrete Leptospira through urine, which contaminate water and soil. People at risk for leptospirosis include farmers, abattoir workers, sewer workers and others who have contact with soil, water and animal [1-3]. The risk during the rainy season becomes higher after flooding when the human population may be exposed to water contaminated with urine from infected animals. The estimated annual leptospirosis morbidity in South and South-East Asia is 17.97 and 55.54 per 100,000 populations [2].

Although data on leptospirosis in Bangladesh is limited, a serological survey in a rural flood prone district of Bangladesh in 1994 showed $38 \%$ seropositivity in 89 samples of human sera tested, indicating that the rural population was at high risk of leptospiral infection [4]. In 2000, acute-phase serum specimens from 359 dengue-negative patients in Dhaka were assessed for leptospirosis. Leptospira spp was detected by polymerase chain reaction (PCR) in $63(18 \%)$ of them [5]. Another study in 2000, screened people with fever in slum of Dhaka city and reported leptospirosis in $8.4 \%$ cases [6]. Presence of leptospirosis among the cattle in dairy farms in Chittagong division of Bangladesh had also been reported [7].

Several diagnostic tests are used to detect acute and past leptospiral infection. Microscopic agglutination test (MAT) is considered as gold standard test for the diagnosis of leptospirosis. But the test requires live organisms. Detection of leptospiral DNA in clinical samples by polymerase chain reaction (PCR) has been employed to diagnose leptospirosis [8,9]. Recently, rLipL32 antigen based serodiagnostic tests have been developed to conduct seroprevalence studies in human leptospirosis [8,10-12]. LipL32 is an outer membrane protein which is highly conserved among pathogenic Leptospira spp and prominent immunogen during leptospirosis. A study from Thailand has shown the diagnostic sensitivity and specificity of the LipL32 dipstick assay as $100 \%$ and $98.33 \%$, respectively when compared to those of MAT. The results suggest that the recombinant LipL32 is a good diagnostic detection reagent for detection of antibodies against Leptospira.

In view of the above, the present study was undertaken to determine the leptospiral infection among rural and urban people of Bangladesh using a rLipL32 based in-house ELISA.

\section{Materials and Methods}

Study population and place: Healthy individuals from two rural areas and febrile cases from one urban healthcare center were enrolled in the study. Rural centers were located at Sonargoan and Bajitpur sub-district (Upozilla) under Narayaganj and Kishorganj districts respectively. Sonargoan is located $26 \mathrm{~km}$ south-east and Bajitpur is located 71 $\mathrm{km}$ north-east of Dhaka city. Individuals with no history of fever in last one month prior to enrollment were considered as healthy and enrolled in the study. Patients with fever for more than 5 days attending an urban healthcare center in Dhaka city were enrolled and were denoted as 'febrile case'.

In order to determine the cut-off optical density (OD) value of ELISA test, blood from 105 healthy newborn babies from a hospital of Dhaka city were included in the study. Samples from neonates were leftover blood collected for other routine investigations. The mothers of the neonates were from urban affluent class and had least chance of exposure to leptospiral infection. About 1-2 ml of blood was collected with aseptic measure and serum was separated and stored at $-200 \mathrm{C}$ until used. Informed consent was obtained from the participants before collection of blood. The study was carried out from April to December 2014.

Determination of anti-rLipL32 IgG antibody by ELISA: Recombinant outer membrane protein of $32 \mathrm{kDa}$, present in pathogenic Leptospira spp, was used for detecting Leptospira spp. specific IgG antibody by enzyme linked immunosorbent assay (ELISA) as described by Voller et al [13].

Recombinant LipL32 protein was over expressed from the recombinant plasmid pAELipL32 which we obtained from Prof. OA Dellagostin, Núcleo de Biotecnologia, Centro de Desenvolvimento Tecnológico, Universidade Federal de Pelotas, Brazil. The recombinant plasmid was transformed into BL21(DE3) plysS strain. For protein purification, positive clone was inoculated into 100 $\mathrm{ml}$ Luria Broth (LB) and allowed to grow at $37^{\circ} \mathrm{C}$ until the OD reached to 0.5 to 0.6 at $600 \mathrm{~nm}$, induced with $1.0 \mathrm{mM}$ IPTG (isopropyl- $\beta-\mathrm{D}$ - 
thiogalactopyranoside) for about 4 hour. Cell pellet was resuspended in BugBuster Protein Extraction Reagent and purified using His $\bullet$ Bind Purification Kit (Novagen, USA). The purified antigen (Fig-1) was reconstituted with sterile distilled water to make a concentration of $1 \mu \mathrm{g} / \mu \mathrm{l}$ and aliquoted for further use. The expression and purification of protein was carried out at Advanced Medical \& Dental Institute, Universiti Sains Malaysia, Malaysia.

The 96 well EIA plate (Linbro, USA) was coated with rLipL32 antigen $5 \mu \mathrm{g} / \mathrm{ml}$ in $0.5 \mathrm{M}$ carbonate/bicarbonate buffer $(\mathrm{pH}$ 9.6). To each well $100 \mu \mathrm{l}$ volume of coating buffer was added and incubated overnight at $4^{0} \mathrm{C}$. The plate was washed three times with PBS- $0.05 \%$ Tween 20 (PBS-T, pH 7.4)) and blocked by incubating for 2 hrs with PBS-T containing $2 \% \mathrm{BSA}$ at $37^{\circ} \mathrm{C}$. The plate was then washed three times with PBS-T. A volume of $100 \mu \mathrm{l}$ serum (1:40 dilutions) sample was added into each well and incubated for 4 hours at $37^{\circ} \mathrm{C}$. After washing with PBS-T three times, $100 \mu \mathrm{l}$ of horseradish peroxidase conjugated antihuman IgG antibodies (1:4000) was added and incubated at $37^{\circ} \mathrm{C}$ for 2 hours. After washing three times with PBS-T, $50 \mu \mathrm{l}$ of TMB substrate was added to each well and incubated at room temperature for 30 minutes in dark. Then $50 \mu \mathrm{l}$ of $1 \mathrm{M}$ sulfuric acid was added in each well. The colour developed was measured by EIA plate reader (Human ELISA Reader) at $450 \mathrm{~nm}$. Optimum concentration of the antigen $(5 \mu \mathrm{g} / \mathrm{ml})$ and serum dilution (1:140) was predetermined by checkerboard titrations. A reagent blank and a positive and negative control wells were included in each plate along with the test samples.

Determination of cut-off $O D$ value: A cut off OD values for rLipL32 specific IgG antibody was determined to find out the exposure rate to Leptospira spp. in the study population. ELISA was performed with sera from 105 healthy newborn babies of Dhaka city who were presumed not to be exposed to Leptospira infection. The mean OD $+3 \mathrm{xSD}$ of these sera were taken as cutoff OD value to determine the exposure rate. The mean $\mathrm{OD} \pm \mathrm{SD}$ of the 105 healthy newborn babies were $0.14 \pm 0.08$. Therefore, the calculated cut-off OD value was $0.38(0.14+3 \times 0.08)$. Any sample showing OD above this cut-off value of 0.38 was considered as positive and referred to as exposed to Leptospira infection.

Determination of Leptospira specific IgG antibody by commercial ELISA: Leptospira specific IgG antibody was also determined by commercial ELISA (DRG International Inc, USA) to compare the results obtained by in-house ELISA using rLipL32 antigen. The kit used purified Leptospira biflexa (serovar patoc 1) antigen for detection of antibody in serum. The assay was carried out as per instruction of the manufacturer.

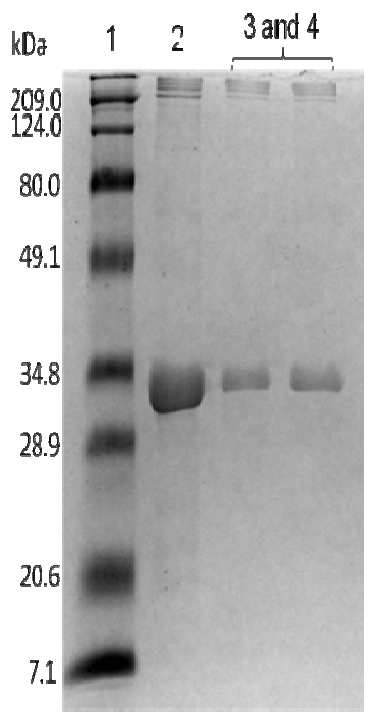

Fig-1. SDS-PAGE showing rLipL32 protein expressed from the recombinant plasmid pAELipL32 and purified using His $\bullet$ Bind Purification Kit (Novagen, USA). Lane 1: Protein ladder, Lane 2: protein following viva spin, Lane 3: protein following acetone precipitation.

\section{Result}

A total of 626 samples were included in the study. Out of which, 376 samples were healthy individuals from rural area and 250 were febrile cases from urban area. Out of total 626 study population, antirLipL32 specific IgG antibody higher than the cutoff OD value $(>0.38)$ were detected in 70 individuals $(11.2 \%)$. The rate of positivity of antirLipL32 antibody among the healthy individuals from rural area (Bajitpur and Sonargaon) was $10.6 \%$, while the rate was $12.0 \%$ in urban population. The detail location wise (urban and 
rural) rate of seropositivity is shown in Table 1 . The rate of positivity in rural and urban population was not significantly $(\mathrm{p}>0.05)$ different.

Table-1: Seroprevalence of anti-leptospiral IgG antibody among rural and urban study population by ELISA using rLipL32 antigen

\begin{tabular}{|c|c|c|c|c|}
\hline & Place & $\begin{array}{c}\text { Total } \\
\text { Number }\end{array}$ & $\begin{array}{c}\text { rLipL32 } \\
\text { IgG } \\
\text { positive } \\
\text { N \% } \\
\end{array}$ & $\begin{array}{c}95 \% \\
\text { CI }\end{array}$ \\
\hline \multirow[t]{3}{*}{ Rural } & Bajitpur & 200 & $23(11.5)$ & $7.4-16.8$ \\
\hline & Sonargoan & 176 & $17(9.7)$ & $5.7-15.0$ \\
\hline & $\begin{array}{l}\text { Bajitpur + } \\
\text { Sonargoan }\end{array}$ & 376 & $40(10.6)$ & $7.7-14.2$ \\
\hline \multirow[t]{2}{*}{ Urban } & Dhaka city & 250 & $30(12.0)$ & $8.2-16.7$ \\
\hline & Total & 626 & $70(11.2)$ & 8.8-13.9 \\
\hline
\end{tabular}

Note: Cut-off value was >0.38. $p>0.05$ compared between rural and urban group; $C I=$ Confidence interval.

Age specific seropositivity rate for anti-rLipL32 antibody is shown in Table-2. Among the urban population, the rate of seropositivity was $9.1 \%$ and $16.4 \%$ in $21-40$ yrs and above 40 years age group respectively; while rate was $7.2 \%$ and $14.0 \%$ in rural population respectively. There was no positive case in age group 1-20 years in urban population while $5.4 \%$ was positive among rural population. There was an increased rate of seropositivity with the increase of age. The overall (rural and urban) rate of leptospira specific rLipL32 antibody was significantly $(\mathrm{p}<0.05)$ higher in people over 40 years of age compared to 21-40 years group (Table-2).
Out of 70 seropositive cases by rLipL32 in-house ELISA, 65 (92.9\%) were found positive by commercial ELISA.

\section{Discussion}

Leptospirosis is an infectious disease with a worldwide distribution. Currently, prevention and control of leptospirosis have received much attention of public health authorities. Improved diagnostic test for leptospirosis is needed to aid clinical diagnosis of acute cases and assess the prevalence. Recently, recombinant antigen based serodiagnostic assays have been developed to diagnose human leptospirosis. Among the many candidate antigens, LipL32, an outer membrane protein, is highly conserved among pathogenic Leptospira spp [12].

In the present study, we have used rLipL32 antigen based ELISA to determine the seroprevalence of leptospiral infection in selected urban and rural population. We have used a cut-off OD of $>0.38$ for our in-house rLipL32 based ELISA to consider a sample positive for leptospiral infection. The results when compared with the commercial ELISA was found almost similar. Positive samples by rLipL32 ELISA was found positive in $92.9 \%$ cases by commercial ELISA. Therefore, rLip32 could be considered as a good candidate antigen for ELISA to detect Leptospira spp specific infection in our geographical locations. However, further study is necessary to optimize the test for detecting anti-leptosipral IgM antibody to detect acute infection.

Table-2: Age specific seropositivity rate of anti-leptospiral IgG antibody of study population by rLipL32 antigen based ELISA

\begin{tabular}{|c|c|c|c|c|c|c|c|c|c|}
\hline \multirow{2}{*}{$\begin{array}{c}\text { Age } \\
\text { Group } \\
\text { (Yrs) }\end{array}$} & \multicolumn{3}{|c|}{ Urban } & \multicolumn{3}{|c|}{ Rural } & \multicolumn{3}{|c|}{$\begin{array}{c}\text { Total } \\
\text { (Rural+Urban) }\end{array}$} \\
\hline & No & $\begin{array}{c}\text { Positive }^{\mathrm{a}} \\
\text { N (\%) }\end{array}$ & $95 \% \mathrm{CI}$ & No & $\begin{array}{c}\text { Positive }^{\mathrm{b}} \\
\text { N (\%) }\end{array}$ & $95 \%$ CI & No & $\begin{array}{c}\text { Positive }^{\text {cd }} \\
\text { N (\%) }\end{array}$ & $95 \% \mathrm{CI}$ \\
\hline $1-20$ & 23 & $\begin{array}{c}0 \\
(0 \%)\end{array}$ & 0 & 37 & $\begin{array}{c}2 \\
(5.4 \%)\end{array}$ & $0.7-18.2$ & 60 & $\begin{array}{c}2 \\
(3.3)\end{array}$ & $0.4-11.5$ \\
\hline $21-40$ & 99 & $\begin{array}{c}9 \\
(9.1 \%)\end{array}$ & $4.2-16.6$ & 139 & $\begin{array}{c}10 \\
(7.2 \%)\end{array}$ & $3.5-12.8$ & 238 & $\begin{array}{c}19 \\
(8.0)\end{array}$ & $4.9-12.2$ \\
\hline$>40$ & 128 & $\begin{array}{c}21 \\
(16.4 \%)\end{array}$ & $10.5-24.0$ & 200 & $\begin{array}{c}28 \\
(14.0 \%)\end{array}$ & $9.5-19.6$ & 328 & $\begin{array}{c}49 \\
(14.9)\end{array}$ & $11.3-19.3$ \\
\hline
\end{tabular}

Note: a. $Z=1.6, p=0.11$, compared between $21-40$ and $>40$ age groups of urban population;

b. $Z=1.95, p=0.06$, compared between $21-40$ and $>40$ age groups of rural population;

c. $Z=1.3$. $p=0.21$, compared between $1-20$ and $21-40$ age groups of total population;

d. $Z=2.5, p<0.05$; compared between $21-40$ and $>40$ age groups of total population;

$C I=$ Confidence interval. 
Leptospirosis has been reported to be prevalent in our neighbouring countries and other countries of South and South-East Asian regions [2]. In India, a 5 year consecutive sero-epidemiological study conducted in Kerala showed that $29.6 \%$ inhabitants possessed anti-leptospiral antibodies [14]. Previous studies from Bangladesh reported $8 \%$ to $38 \%$ leptospira infection among febrile cases from urban and rural areas of the country [4-6]. But there is no study regarding the sero-prevalence of leptospiral infection among healthy rural Bangladeshi population. In the present study, prevalence of leptospirosis was found $12 \%$ among the febrile urban population and $10.64 \%$ among the healthy individuals from rural areas. The rate of infection was not significantly different among urban febrile cases and healthy individuals of rural areas. However, the overall rate of infection increased significantly with the increase of age. Previous studies reported that older people (20 years and above) were at a greater risk for leptospirosis than children [2].

Presence of rLipL32 specific IgG among our study population has shown that leptospiral infection is prevalent both in rural and urban areas of Bangladesh. Anti-leptospiral IgG remains persistent for several years following acute infection [15-16]. Persistence of antibody may create problem in interpreting the serological tests detecting $\mathrm{IgG}$ antibodies in acute cases unless rising IgG antibody or Leptospira specific IgM is detected.

The present study has demonstrated that a large proportion of people residing in both rural and urban areas of Bangladesh are exposed to leptospiral infection and rLipL32 antigen is a potential candidate for the serodiagnosis of leptospirosis.

\section{References}

1. Jackson LA, Kaufmann AF, Adams WG, Phelps MB, Andreasen C, Langkop CW, et al. Outbreak of leptospirosis associated with swimming. Pediatr Infect Dis J. 1993; 12: 48-54.

2. Costa F, Hagan JE, Calcagno J, Kane M, Torgerson $\mathrm{P}$, Martinez-Silveira MS, et al. Global morbidity and mortality of leptospirosis: a systematic review. PLoS Negl Trop Dis.
2015; 9(9): e0003898. doi:10.1371/ journal. pntd.0003898.

3. Whitney EAS, Ailes E, Myers LM, Saliki JT, Berkelman RL. Prevalence of and risk factors for serum antibodies against Leptospira serovars in US veterinarians. J Am Vet Med Assoc. 2009; 234: 938-944.

4. Morshed MG, Konishi H, Terada Y, Arimitsu Y, Nakazawa T. Seroprevalence of leptospirosis in a rural flood prone district of Bangladesh. Epidemiol Infect. 1994; 112: 527-31.

5. LaRocque RC, Breiman RF, Ari MD, Morey RE, Janan FA, Hayes JM, et al. Leptospirosis during dengue outbreak, Bangladesh. Emerg Infect Dis. 2005; 11(5): 766-769.

6. Kendall EA, LaRocque RC, Brooks WA. Leptospirosis as a cause of fever in urban Bangladesh. Am J Trop Med Hyg. 2010; 82: 6 1127-1130.

7. Parvez MA, Prodhan MAM, Rahman MA, Faruque MR. Seroprevalence and associated risk factors of Leptospira interrogans serovar Hardjo in dairy cattle of Chittagong, Bangladesh. Pak Vet J. 2015; 35(3): 350-354.

8. Musso D, Scola BL. Laboratory diagnosis of leptospirosis: A challenge. J Micro Immu Infec. 2013; 46: 245-252.

9. Ahmed SA, Sandai DA, Musa S, Hoe CH, Riadzi M, Lau KL, Tang TH. Rapid diagnosis of leptospirosis by multiplex PCR. Malays $J$ Med Sci. 2012; 19(3): 9-16.

10. Boonyod D, Poovorowan Y, Bhattarakosol P, Chitrathaworn C. LipL32, an outer membrane protein of Leptospira, as an antigen in a dipstick assay for diagnosis of leptospirosis. Asian Pac J Allergy Immunol. 2005; 23: 133-141.

11. Flannery B, Costa D, Carvalho FP, Guerreiro $\mathrm{H}$, Matsunaga J, da Silva ED, et al. Evaluation of recombinant leptospira antigen-based enzymelinked immunosorbent assays for the serodiagnosis of leptospirosis. J Clin Microbiol. 2001; 39: 3303-10.

12. Haake DA, Chao G, Zuerner RL, Barnett JK, Barnett D, Mazel M, et al. The leptospiral major outer membrane protein LipL32 is a 
lipoprotein expressed during mammalian infection. Infect Immun. 2000; 68: 22762285.

13. Voller A, Bartlett A, Bidwell DE. Enzyme immunoassays with special reference to ELISA techniques. J Clin Path. 1978; 31: 507-520.

14. Kuriakose M, Paul R, Joseph MR, Sugathan S and Sudha TN. Leptospirosis in a midland rural area of Kerala State. Indian J Med Res. 2008; 128(3): 307-312.
15. Cumberland P, Everard CO, Wheeler JG, Levett PN. Persistence of anti-leptospiral IgM, IgG and agglutinating antibodies in patients presenting with acute febrile illness in Barbados 1979-1989. Eur J Epidemiol. 2001; 17(7): 601-608.

16. Finsterer J, Stöllberger C Sehnal E, Stanek G. Mild leptospirosis with three-year persistence of IgG- and IgM-antibodies, initially manifesting as carpal tunnel syndrome. J Infec. 2005; 51(2): E67-70. 